ESJ Humanities

\title{
Great Power Politics in Post-Cold War Period: The Ukraine Crisis of 2014
}

\author{
Vitalis Mbah Nankobe \\ Simon Fraser University, \\ Department of Political Science, Vancouver, Canada
}

Doi:10.19044/esj.2021.v17n33p1

Submitted: 14 August 2021

Accepted: 13 September 2021

Published: 30 September 2021
Copyright 2021 Author(s)

Under Creative Commons BY-NC-ND

4.0 OPEN ACCESS

Cite As:

Nankobe V.M. (2021). Great Power Politics in Post-Cold War Period: The Ukraine Crisis of 2014. European Scientific Journal, ESJ, 17 (33), 1.

https://doi.org/10.19044/esj.2021.v17n33p1

\section{Abstract}

The Ukraine Crisis of 2014 which led to the annexation of Crimea by Russia has been one of the worst European issues since the end of the Cold War. NATO's relations with Russia have worsened ever since Russian troops invaded and annexed the Crimean peninsula in 2014. This paper examines why Russia intervened and eventually annexed Crimea during the Ukraine crisis through theoretical approaches in IR (international relations). In addition, the paper also discusses the consequences of Russia's actions in Crimea during the Ukraine Crisis of 2014. This paper argues that Russia intervened and annexed Crimea during the Ukraine Crisis of 2014 because of NATO's expansion policy in eastern Europe. The study was conducted using a qualitative and a non-positivist approach to research (interpretivist) which is centered on the humanistic view of the social sciences. On the one hand, the findings of this study support my central thesis; it revealed that NATO's expansion policy in eastern Europe was the cause of Russia's actions in Crimea during the Ukraine Crisis of 2014. On the other hand, the findings of this study revealed that there are alternative factors that also motivated Russia to intervene and annex Crimea from Ukraine such as nationalism, identity, and Russia's quest for great power status. Further, Russia's invasion and eventual annexation of Crimea without the consent of Ukrainian authorities had several consequences. For instance, it caused tension between Russia and NATO, increased military spending, and led to numerous international sanctions. 
Keywords: Ukraine Crisis, Intervention, Annexation, Crimea, NATO, Russia

\section{Introduction}

Great Power Politics is a concept commonly used by scholars in the field of international relations (IR). In the IR field, "great power politics" refers to the pursuit of material power by powerful states in the international system to achieve security (Abebe, 2009: 4). John Mearsheimer a political scientist and a leading IR scholar who belongs to the realist school of thought contends that the period of great-power rivalry is not over because major powers still fear each other in the contemporary world (Mearsheimer, 2001). Mearsheimer's view is built on an "offensive realist" theory of world politics which assumes that the deep insecurity generated by the anarchic international system makes great power to act aggressively toward each other preventing rivals from gaining power even if such moves risk war (Mearsheimer, 2001: 36). This paper systematically analyzes the Ukraine Crisis of 2014 between Russia and the West which is one critical incident of contemporary great power politics. By Ukraine crisis, I am referring to Russia's intervention and annexation of Crimea in 2014.

The paper looks at the background conditions, causes, and consequences of the Ukraine Crisis of 2014. The crisis which led to Russia's annexation of Crimea represents the biggest geopolitical shock to the European security system since the end of the Cold War (Larsen, 2014: 7). Over the years, there have been conflicting debates on the reasons behind Russia's intervention and annexation of the Crimean peninsula during the Ukraine Crisis of 2014. For example, on the one hand, some scholars claimed that Russia intervened in Ukraine and annexed the Crimean peninsula to protect its nationals from the chaos in Ukraine following the ousting of Ukraine's pro-Russian president Yanukovych (Balouziyeh, 2014). On the other hand, some scholars argue that Russia annexed the Crimean peninsula because of its geopolitical ambitions (Treisman, 2016: 47). Because of these debates, it is therefore important to find out the true reasons behind Russia's intervention and annexation of Ukraine's Crimean peninsula in 2014. Hence, a central aim of this paper is to analyze the rationale behind Russia's intervention and annexation of Crimea during the Ukraine Crisis of 2014 through theoretical approaches in IR. John W. Creswell explains that the research questions of a study should be a broad attempt for exploring the central phenomenon of the study (2009: 129). Therefore, the formulated research question of this study is:

- Why did Russia intervene and annex Crimea during the Ukraine Crisis of 2014 ? 
I decided to ask the research question above because I thought it would be interesting to know why Russia behave the way it did in Crimea during the Ukraine Crisis of 2014. Besides, this crisis is an interesting topic because it is one of the most talk-about crises in recent years. Moreover, the crisis is one of the worst post-Cold War security crises that have worsened relations between Russia and the West, thereby threatening international peace and security. This paper argues that Russia intervened and annexed Crimea during the Ukraine Crisis of 2014 because of NAT0's expansion policy in eastern Europe.

\section{Historical Background}

Before 2014, the Crimean peninsula was officially part of Ukraine; however, Crimea had its own parliament and government with power over agriculture, tourism, and public infrastructure (Buchanan, 2014). The majority of Crimea's population is made up of ethnic Russians, while Ukrainians and Crimean Tatar make up the minority population. In the "Budapest Memorandum" signed by Russia, Ukraine, the UK, and the United States in 1994, the UK, Russia, and the United States essentially consecrated the sovereignty and territorial integrity of Ukraine as an independent state (Deutsche Welle, 2014). In other words, Russia and these western countries promised that none of them would ever threaten or use force against the territorial integrity or political independence of Ukraine (Ibid). However, Russia decided to violate this accord when it decided to use force to invade and annex Crimea in 2014 without permission from the Ukrainian government.

The events that led to the annexation of Crimea started in November 2013 when Viktor Yanukovych, who was president at the time and proRussian, decided to suspend the signing of the Ukraine-European Union Association Agreement. He refused to sign this agreement with the EU because he was pro-Russian and because he came to power in 2010 with the support of ethnic Russian voters in Crimea and eastern Ukraine. He openly stated in the media that he was rejecting the EU agreement because "Ukraine could not afford to sacrifice trade with Russia who opposes the deal" (Ibid), proving his strong allegiance to Russia.

The protest that started against President Viktor Yanukovych in late November 2013 intensified until early 2014 when he was ousted from power by pro-EU protesters in Kiev, Ukraine's capital city. The ousting of Ukraine's pro-Russian President Viktor Yanukovych angered Russian President Vladimir Putin and he decided to send Russian armed forces to take over control of Crimea from Ukraine. After taking over control of Crimea from the Ukrainian government, authorities in Crimea with the help of Russia hastily organized an independence referendum on March 16, 2014, for citizens of Crimea to decide if they wanted to become part of Russia. Because the 
majority population of Crimea was ethnic Russians, the territory voted overwhelmingly (97\%) to become part of Russia (Ibid).

Following the referendum, Russia annexed Crimea in early 2014 and made it part of Russia. The independence referendum, the annexation of Crimea, and its subsequent incorporation into the Russian Federation caused serious tension between Russia and the West. Ukraine and many western countries condemned the referendum and Russia's annexation of Crimea as illegal (Christie, 2015). On the other, Russia and authorities in Crimea argued that the referendum was legal. The discourse of "two Ukraine" has dominated debates in the country since independence and shaped its perception in the West and Russia (Zhurzhenko, 2014: 249). This discourse juxtaposes the Ukrainian-speaking Pro-European west and the Pro-Russian east as two historical and cultural entities, informed by conflicting memories and antagonistic identities that have little chance of coexisting as a united country. The Ukraine Crisis of 2014 has attracted the attention of many scholars around the world and several studies have been conducted on the crisis (for example, Costea, 2016; Sperling and Webber, 2017).

However, most scholars that have conducted studies on the 2014 Ukraine crisis looked at the crisis from different perspectives. For instance, Ana-Maria Costea in 2016 conducted a study on the Ukraine Crisis of 2014. Her study analyzed the degree to which the events from the Ukraine Crisis of 2014 were predictable. She conducted her study using documentary analysis (both primary and secondary sources). She argued that the events from the Ukraine Crisis of 2014 do not pose themselves as a surprise because almost all the elements that were developed or were already present there were predictable (Costea, 2016: 344). Costea explains that in Ukraine, the domestic fragmented situation between the voters created huge discrepancies in terms of political choices and ultimately centrifugal behaviors (Costea, 2016: 345). Another genre of writing on the Ukraine Crisis of 2014 is the work of James Sperling and Mark Webber conducted in 2017. The authors looked at the impact of the Ukraine Crisis of 2014. Their findings revealed that the Ukraine Crisis of 2014 has resulted in Russia being explicitly identified as a source of threat by NATO which has triggered a successful collective re-securitization by the Alliance (2017: 19). In addition, they argued that a framework that demonstrates NATO's standing as a securitizing actor has potential relevance to other regional security organizations (Sperling and Webber, 2017: 22).

\section{Literature Review}

This section reviews the existing literature on the independent variable of the research question of this paper (the causes of Russia's intervention and annexation of Crimea). It reviews the existing literature under the following 
subheadings "causal argument" and "debates in the literature/scholarly contributions."

\subsection{Causal Argument}

As aforementioned, few studies have been conducted on the reasons for Russia's intervention and annexation of Crimea during the Ukraine Crisis of 2014. These studies present competing independent variables on why Russia intervened and annexed Crimea during the crisis. For example, a study by Roy Allison in 2014 assessed in detail the reasons for Russia's military intervention in the Ukraine Crisis of 2014 which led to the annexation of Crimea. Allison argued that there are two reasons why Russia intervened in the Ukraine Crisis of 2014 (1) geopolitical competition (2) identity and ideational factors (2014: 1268-1294). Allison explained that these two reasons played a role in Russia's intervention and annexation of Crimea in 2014. Another study conducted by David Lane in 2016 examines the motivations for Russia's actions in the Ukraine Crisis of 2014. Unlike Allison who argued that Russia intervened in Ukraine because of geopolitical, identity, and ideational factors, Lane argued that Russia intervened in the Ukraine crisis and annexed Crimea from Ukraine because of the expansion of NATO in eastern Europe (Lane, 2016: 502-503).

Mearsheimer 2014; Bebler 2015; Ericson \& Zeager 2015 all agree with Lane that NATO's expansion policy in eastern Europe near Russia's borders pushed Russia to annex Crimea from Ukraine during the Ukraine Crisis of 2014. Similarly, Davis Christopher 2016 and Kamp Karl-Heinz 2014 contend that NATO's expansion policy eastward near Russia's borders pushed Russia to intervened and annexed Crimea from Ukraine during the Ukraine Crisis of 2014. On the other hand, (Lindley-French 2014; Kuzio \& D'Anieri 2018; Masters 2020) seem to disagree. They do not see NATO's expansion policy in eastern Europe as the cause of Russia's intervention and annexation of Crimea during the Ukraine Crisis of 2014. However, they agree with Allison that Russia intervened and annexed Crimea during the crisis because of its geopolitical considerations (Lindley-French 2014; Kuzio \& D'Anieri 2018; Masters 2020).

Furthermore, Viacheslav Morozov in 2017 analyzed why the majority of Russian citizens in Russia supported Russia's intervention and annexation of Crimea during the Ukraine Crisis of 2014. The author argued that the majority of Russians supported Russia's intervention and annexation of Crimea in 2014 because of the propaganda spread by the Russian government about the West and because of the idea of "Russian identity" (Morozov, 2017: 4). Marozov contends that most Russians view the people of Crimea and Russia as one people which made them to support Putin's move to annex Crimea from Ukraine during the 2014 Ukraine crisis. Teper confirms 
Marozov's argument when he argued that the notion of protecting "Russian identity" also motivated Russia to annex the Crimean peninsula from Ukraine because the majority population of Crimea was ethnic Russians and Russia saw these people as Russians (Teper, 2015: 380).

Again Averre (2016) and Zhurzhenko (2014) also agree with Teper and Marozov that Russia was forced to behave the way that it did in Crimea during the Ukraine Crisis of 2014 because it wanted to protect the "Russian national identity" since it saw the people of Crimea as Russians. Zhurzhenko went further to argue that during the Ukraine Crisis, Russia increased its support for pro-Russian groups and organizations in eastern Ukraine especially those that defended the Russian speakers against "Ukrainization" and opposed the pro-Western course of the Ukrainian government (2014: 258). Finally, another study conducted by Daniel Treisman in 2016 analyzed the reasons why Russian president Vladimir Putin took Crimea from Ukraine during the Ukraine Crisis of 2014. The findings of Triesman's study also revealed that Russia intervened in the Ukraine Crisis of 2014 and annexed Crimea because of the threat of NATO's expansion (Triesman, 2016: 47). Triesman argued that by annexing Ukraine's territory by force, Putin overturned in a single stroke the assumptions on which post-Cold War European order had rested (Ibid).

\subsection{Debates in the Literature/Scholarly Contribution}

The findings of the aforementioned studies reviewed above have revealed significant debates on the reasons that influenced Russia's intervention and eventual annexation of Crimea during the Ukraine Crisis of 2014. The literature reviewed shows that work on the reasons why Russia intervened and annexed Crimea during the crisis can be divided into three main groups. The first group emphasizes NATO's expansion in eastern Europe as the main reason behind Russia's intervention and annexation of Crimea during the 2014 Ukraine crisis (Mearsheimer, 2014; Bebler, 2015; Wolff, 2015; Lane; 2016; Davis, 2016; Kamp, 2014; Triesman, 2016; Ericson $\&$ Zeager, 2015). This group portrays Russia as a defender (a passive victim compelled to respond to NATO's expansion). The second group focuses on Russian geopolitical expansion as the cause of Russia's behavior in Crimea (Lindley-French, 2014; Kuzio \& D'Anieri, 2018; Allison, 2014; Masters, 2020). The third group of scholars sees Russia's annexation of Crimea in 2014 as an effort by the Russian government to reassert "Russian national identity" which sees Russia as a civilization that extends beyond Russia's boundaries (Morozov, 2014; Teper, 2015; Allison, 2014; Zhurzhenko, 2014; Averre, 2016).

Of these three groups presented above, I stand on the side of the first group (NATO's expansion). In other words, I believe the argument made by 
scholars who argued that NATO's expansion policy in eastern Europe motivated Russia to annex Crimea is more persuasive than the arguments made by those from the geopolitical and identity groups. The reason for my stand is because I was looking at the number of evidence presented by scholars from the three groups and I realized that scholars from the NATO expansion group presented more evidence to back up their argument than scholars who argued that geopolitical or identity factors were responsible for Russia's action in Crimea. For instance, scholars from the first group who argued that NATO's expansion caused Russia to intervene and annex Crimea used more statements from Russian state officials as evidence than scholars in the "geopolitical" and "identity" groups. In other words most of the evidence in the literature that I read points to NATO's expansion as the main reason for Russia's actions in Crimea than the geopolitical and identity arguments. There is a lack of sufficient evidence in the literature that I read to justify that identity and geopolitical factors caused Russia to intervene and annex Crimea in 2014.

Moreover, another reason why the first group (NATO's expansion) is more persuasive than the geopolitical and identity group is that scholars from NATO's expansion group present more valid arguments than scholars from the geopolitical and identity groups. For instance, scholars from the NATO expansion group argued that even before the Ukraine Crisis of 2014, Russia had always seen NATO as an opponent to its military might. Thus, Russia's views about NATO made it annex Crimea to prevent its opponent from establishing near its borders. This argument is valid because Russia has indeed seen NATO as a rivalry force long before the Ukraine crisis. Russia and NATO had clashed on several occasions long before the Ukraine Crisis of 2014 like in the Cold War, which makes both sides view each other as a rival.

Furthermore, it is insufficient to think simply in terms of geopolitical competition between Russia and the West with Crimea as the proving ground. In other words, Russia would have annexed more territories in eastern Europe if it was really out for geopolitical expansion in the region and not just Crimea. Besides, the identity argument is less convincing because Russia's choice to identify with ethnic Russians, Russian-speakers, and Russian 'compatriots' in the crisis was useful in generating domestic support for coercive action in Crimea. The scholars who argued that Russia's annexation of Crimea was to protect Russian citizens and the Russian ethnic identity present insufficient evidence to show that ethnic Russians in Crimea were under real threat from the Ukrainian government at the time. Thus, the identity argument does not offer significant explanatory value for such extreme Russian behavior at the specific time it occurred. Likewise, the argument made by the Russian government on the media that it intervened and annexed Crimea to protect ethnic Russians in Crimea seems more like justification as opposed to true intention. 
The literature reviewed above revealed that the academic literature has seen a tendency for scholars to resurrect previous debates rather than offering an in-depth analysis of the implications of Russia's actions in Crimea during the Ukraine Crisis of 2014. In other words, most of the literature that I read does not explore the consequences of Russia's actions in Crimea during the Ukraine crisis. I will address this gap by discussing the consequences of Russia's action in Crimea. As earlier mentioned, the literature reviewed shows that only a limited number of studies have been conducted on the Ukraine Crisis of 2014 using the English language. This study will add to the limited number of studies that have been conducted on the Ukraine Crisis of 2014 in English.

\section{Theoretical/Conceptual Framework}

This section defines and operationalizes three relevant concepts used in this study: "defensive realism", "offensive realism" and "national interest."

\subsection{Defensive Realism}

Defensive realism is part of structural realism theory also known as neorealism, which is a subset of the realist school of thought in international relations (IR). Realism is considered as the most dominant paradigm in IR theory since World War II (Antunes \& Camisao, 2018: 1). Other mainstream IR theories are liberalism, constructivism, and the English School. Defensive realism theory was developed by Kenneth Waltz; Waltz's defensive realism offers a systemic and state-centric theory of international politics (Pashakhanlou, 2018: 4). The structural components of Waltz's defensive realism consist of "anarchy" defined as the absence of government and the distribution of capabilities across the international system (Waltz, 1979: 88). Waltz argues that the anarchic nature of the international system encourages states to undertake defensive and moderate policies to attain security. Similarly, Waltz contends that states do everything for their survival in a world where their security is not assured (Waltz, 1979: 92). Waltz makes two explicit assumptions regarding states in his defensive realism theory. First, he assumes that states are unitary actors that only differ in their capabilities (Ibid). Second, he assumes that states pursue policies to ensure their own survival (Waltz, 1979: 118). Waltz believes that the balance of power is an "iron law" that states can use to assure their survival by making sure that none of their rivals grow too powerful. According to Waltz, great powers possess the greatest capabilities to shape the character of the international system (1979, 129: 130). Waltz contends that a bipolar system where the balance is maintained by two great powers is more stable than a multipolar system in which the anarchic system is inhabited by three or more great powers (1979: 161). His defensive realism theory asserts that aggressive expansion as promoted by offensive 
realists upsets to conform to the balance of power theory, thereby decreasing the primary objectives of states which is to ensure their security. Defensive realism assumes that states are not intrinsically aggressive and that the main concern of states is not to maximize power but to maintain their positions in the international system.

\subsection{Offensive Realism}

On the other hand, offensive realism is a structural theory developed by John J. Mearsheimer, a mainstream scholar in the neorealist camp (Steinsson, 2014: 2). Neorealist, Mearsheimer developed his offensive realism theory in response to Kenneth Waltz's defensive realism theory. Mearsheimer's offensive realism theory employs a system-centric approach to study states' behavior at the international level. The theory departs from classical realism and employs positivism as a philosophy of science. Offensive realism holds that the international system is anarchic and the anarchic nature of the international system drive states to pursue aggressive behavior in international politics. Mearsheimer's offensive realism theory mainly focuses on how powerful countries (great powers) such as the U.S, Russia, France, and the UK pursue power in international politics (Mearsheimer, 2010: 72).

Mearsheimer bases his theory of offensive realism on five assumptions. The five assumptions explain why states maximize their relative power, think, and act offensively toward each other at the international level. The five assumptions or basic tenets of offensive realism theory are as follows: (1) Powerful countries or great powers are the main actors in world politics and the international system is anarchic, which means that there is no hierarchy or superior power that can control the behavior of states (Mearsheimer 2001: 30). (2) States inherently possess some offensive military capabilities which they are capable of using against other states (Mearsheimer, 2001: 31). (3) No state can be certain about other states' intentions. States always want to know whether other states are determined to use force (Ibid). (4) The most basic motive driving state is survival. In other words, states seek to maintain their survival (their territorial integrity and domestic autonomy) above other goals (Ibid). (5) States are rational actors and they think strategically to maximize their prospects for survival (Mearsheimer, 2001: 31). Mearsheimer noted that other than these five assumptions, realist scholars like him share the belief that power is the currency of international politics (Mearsheimer, 2010: 74). Likewise, Mearsheimer explained that these five conditions or assumptions of offensive realism have created a situation where states fear each other. They fear each other and view each other as a potential enemy which has led to the belief that the best way to guarantee their security is to achieve hegemony, not the balance of power (Ibid). 
Mearsheimer's Offensive realism theory assumes that powerful states do everything to maximize their relative power, not absolute power until hegemony is achieved. His offensive realism theory portrays the international system as a jungle where each state relies on self-help for its survival. Also, Mearsheimer's offensive realism theory starts with similar assumptions as Kenneth Waltz's defensive realism theory but reaches dissimilar conclusions. For example, both theories start with similar assumptions for anarchy, the capabilities assumption, and the survival assumption. However, as can be seen from above, a central conclusion reach by Waltz is that of the balance of power. Waltz argues that a recurrent pattern of balancing occurs where states ally with weaker states to balance stronger states (Waltz, 1979: 117). Contrarily, Mearsheimer rejects Waltz's conclusion and argues that states can never truly be secure and that states can only ensure their survival through power maximization (Mearsheimer, 2001: 61). In other words, Mearsheimer concludes that the best way for states to guarantee their security is to achieve hegemony, not the balance of power.

\subsection{National Interest}

Another IR concept used in this paper is Weldes' concept of "national interest." Weldes Jutta is a critical scholar from the critical constructivist camp in IR theory. Other critical approaches to IR are feminist, critical theorist, neoMarxist, neo-Gramscian, and post-structuralist. Weldes criticize the conventional realist notion of "national interest." Drawing from Alexander Wendt, Weldes provides a constructivist reconceptualization of national interest (Weldes, 1996: 280). Her concept of national interest employs a critical constructivist approach to study states' behavior at the international level. In addition, her concept of national interest employs post-positivism as a philosophy of science. Weldes argues that "national interest" is an important concept to study international politics and states' actions because it is the language that states use to justify their actions at the international level and to create their foreign policy (Weldes, 1996: 276). Moreover, Weldes contends that the concept of national interest is important in world politics for two reasons: (1) it is through the concept of national interest that policymakers understand the goals to be followed by a state's foreign policy. (2) The concept of national interest acts as a rhetorical device through which the legitimacy and political support for state action are generated (Ibid). Thus, the concept of national interest helps to create and legitimize the actions taken by states at the international level. From a critical constructivist standpoint, Weldes explains that the concept of national interest should be understood as a social construction. She argues that before state officials can act on behalf of a state, they must engage in a process of interpretation to understand the situation that they face and how they should respond to it (Weldes, 1996: 276-277). 
According to Weldes, the process of interpretation requires a shared language from state officials who are responsible to decide for the state and the audience for whom the state action must be legitimate. Weldes maintains that the shared language is that of "national interest" (Ibid). Moreover, Weldes explains that the content of national interest is produced in a process of representation through which state officials and others understand their international context. She assumes that national interest is constructed and that the national interest is created as a meaningful object, out of share meaning through which states' action in the international system is understood (Weldes, 1996: 277). I used Weldes' concept of national interest, Waltz's defensive realism theory, and Mearsheimer's offensive realism theory in my analysis to explain why Russia intervened and eventually annexed Crimea during the Ukraine Crisis of 2014.

\section{$5 \quad$ Methodology \\ 5.1. Methods and Scope of Research}

To start with, this study was conducted using a qualitative and a nonpositivist approach to research (interpretivist) which is centered on the humanistic view of the social sciences. I used the process-tracing method for this study because of the need to establish a causal mechanism and explain why Russia intervened and annexed Crimea during the Ukraine Crisis of 2014. The process-tracing method is where the researcher seeks to find observable implications of hypothesized claims (Bennet, 2010). In this study, I hypothesize that NATO's expansion policy in eastern Europe is the underlying cause of Russia's intervention and annexation of Crimea. Hence, I traced the cause which is my independent variable (NATO's expansion) to the effect, my dependent variable (the intervention and annexation of Crimea). As Bennet explains, process tracing is useful in this regard because it allows for a forward and backward trace of the cause to the effect under investigation.

In terms of case selection techniques, I employ a "typical case selection technique."

Gerring explained that a typical case selection technique intends to explore a typical case of some phenomena (2017: 22). The topic of this paper (the Ukraine Crisis of 2014) is an example of a typical case. I decided to use this technique rather than other techniques such as the extreme case or the deviant case technique because I wanted to study the casual process in-depth. As Gerring explained, with the typical case selection technique, the researcher selects to study the causal process in depth (Ibid). Furthermore, this study was conducted using qualitative secondary data collected from publicly available documents (articles). Qualitative data are very useful in a study like this one that focuses on a single case or event (Gerring, 2017: 20). The documents were collected electronically from the internet. 
Although it would have been nice to conduct this study using other sources of data such as primary data from interviews, I decided to use publicly available documents because it saves more time than gathering data from other sources such as surveys and in-depth interviews. Besides, the documentary analysis method that I used in this study is in line with the methods used by other researchers that have conduct research on this topic as can be seen in the literature review section. The data consist of online articles on Russia's intervention and annexation of Crimea from 2014 to 2020. This time frame was selected because it covers the period when there were a lot of discussions in the media about the Ukraine Crisis of 2014. I coded my data using NVivo to identify major themes used in the articles to explain why Russia intervened and annexed Crimea during the Ukraine Crisis of 2014. I decided to code my data using NVivo because the presence of nodes in NVivo provides "a simple to work with structure" for creating codes and discovering themes (Zamawe, 2015: 5).

As aforementioned, the theories of offensive realism, defensive realism, and national interest guided my analysis of why Russia intervened and annexed Ukraine's Crimean peninsula during the Ukraine Crisis of 2014. This study intended to develop explanations direct from the data. As a result, the theories were constructed from the data, hence, an inductive approach. Furthermore, David Silverman recommends that as researchers, we should try to use concepts and theories that are closely related to our discipline (2006: 6). The three concepts/theories used are appropriate for this study because scholars in the IR field often used them to analyze wars and international conflicts. Next, I analyzed my data using qualitative content analysis (QCA). Qualitative content analysis can be defined as a research method for subjective interpretation of the content of text data through the systematic classification process of coding and identifying themes or patterns (Hsieh \& Shannon, 2015: 1278) QCA has been identified by numerous scholars as one of the best methods to study texts or documents. I used QCA to look at how language was used in the articles to explain why Russia intervened and annexed Crimea during the Ukraine Crisis of 2014 and to identify major themes in the articles. The following question guided my analysis: (1) what motivated Russia to intervened and annexed Crimea during the crisis? This question helped me to identify key themes used in the data to talk about the rationale behind Russia's actions in Crimea.

I structured the presentation of my evidence in the result section first by presenting evidence that Russia intervened and annexed Crimea from Ukraine during the Ukraine Crisis of 2014 because of the threat of NAT0's expansion near its borders. Next, I present evidence of alternative arguments on why Russia behaved the way it did in Crimea during the Ukraine Crisis of 2014. The evidence that I present in the results section is sentences from my 
data (the articles). I presented the evidence under different themes that emerged from my data. And I employ an interpretive approach to research by using these sentences from the articles to explain why Russia intervened and annexed Crimea during the Ukraine Crisis of 2014. To limit the scope of this study, this study focused mainly on Crimea and the events that occurred there during the Ukraine Crisis of 2014. This study is not interested in other aspects of the crisis such as the legality of Russia's intervention and annexation of Crimea or the debates on whether the Ukraine crisis was the West's or Russia's fault.

\section{Results and Analysis}

This section of this paper presents the results and analysis to answer the research question: Why did Russia intervene and annex Crimea during the Ukraine Crisis of 2014?

It presents and discusses the results of the text analysis of the articles that I examined in this study. As aforementioned, I got the findings of this study by using qualitative content analysis to look at how language was used in my data to explain the rationale behind Russia's actions in Crimea during the Ukraine Crisis of 2014. My findings revealed that Russia intervened and annexed Crimea during the Ukraine Crisis of 2014 because of NATO's expansion policy in eastern Europe. This finding is in line with the central thesis/argument of this paper. However, my findings also revealed that they are alternative arguments on the rationale behind Russia's intervention and annexation of Crimea in 2014. The results will be presented and analyzed under the following themes that emerged from my data: "NATO's expansion", "great power status", "Nationalism and Russian national identity."

\subsection{Why Russia Intervened and Annexed Crimea in 2014 6.1.1. NATO's Expansion}

After coding my data with NVivo "NATO's expansion" emerged as a central theme to explain the rationale behind Russia's intervention and annexation of Crimea. For instance, one article by Charles Ziegler stated that "Russia intervened and annexed Crimea in 2014 because NATO's expansion in eastern Europe threatened Russia's security" (2020: 14). Similarly, another article stated that "Russian President Vladimir Putin admitted in a televised interview in Spring 2014 that Russia's annexation of Crimea, home to its Black Sea Fleet, was partly influenced by NATO's expansion into eastern Europe" (Reuters, 2014). Again, another article stated that "Russia was forced to act in Crimea because of the expansion of western institutions such as NATO near Russia's borders" (Walker, 2014). The above statements from my data show that Russia intervened and annexed Crimea during the Ukraine Crisis of 2014 because of NATO's expansion policy in eastern Europe. This 
finding is similar to the findings of Lane 2006; Mearsheirmer 2014; Triesman 2016; Bebler; 2015 and others discussed in the literature review section of this paper. Russia's decision to intervene and annex Crimea from Ukraine because of NATO's expansion policy can be analyzed using both Kenneth Waltz's defensive realism and John Mearsheimer's offensive realism as can be seen below.

To start with, The North Atlantic Treaty Organization (NATO) was founded in 1949 by the United States, Canada, and other western European countries to oppose and contained the Soviet Union. Before the Ukraine crisis and the annexation of Crimea in 2014, Russia had always seen NATO as an opponent and a threat to its security (Brent, 2018). In addition, Russia has been against NATO"s expansion policies in eastern Europe since the collapse of the Soviet Union (Ibid). However, the alliance has been ignoring Russia's opposition to its expansion policy in eastern Europe over the years by admitting eastern European states as new members into the alliance. The first round of NATO's expansion policy in eastern Europe occurred in 1999 when Czech Republic, Hungary, and Poland joined the alliance. The second enlargement took place in 2004 when Bulgaria, Estonia, Latvia, Lithuania, Romania, Slovakia, and Slovenia joined NATO (Mearsheimer, 2014: 78).

The move by these countries to join NATO antagonized Russia because these countries belonged to the former Soviet Union. The situation became worse in 2008 when NATO announced that it would accept Georgia and Ukraine as new members of its alliance. The move further antagonized Russia because these two countries share a border with Russia. Russia saw the possibility of its closest neighbor to the south (Ukraine) joining NATO as a direct threat to its security. Russian President Vladimir Putin echoed these sentiments when he openly told the West that admitting Ukraine and Georgia as NATO members would be "a direct threat to Russia" (Mearshiemer, 2014:79). Russia understood that Ukraine joining NATO would mean that Russia's Black Sea Fleet will be evicted from its long-standing base in the Crimean city of Sevastopol and NATO's navy will be station in this city. Russia understood that if this happened, it would create a real threat to the whole of southern Russia.

To prevent Russia from losing the Crimean city of Sevastopol as a result of Ukraine joining NATO and to halt NATO's expansion near its borders, Russia decided to intervene in eastern Ukraine and annex the strategic Crimean peninsula. Russia's decision to intervened and annexed Crimea because of NATO's expansion near its borders was motivated by legitimate security concerns. In this scenario NATO can be seen as an aggressor provoking Russia while Russia can be seen as a defender, defending its territory from the perceived security threat pose by NATO's expansion near its borders. In other words, Russia can be seen as a defensive realist as 
explained by Waltz in his defensive realism theory (Waltz, 1979). Likewise, Russia's action is an example of defensive state behavior in international politics as Waltz explains in his defensive realism theory. The defensive action taken by Russia to annex Crimea because of the threat pose by NATO's expansion near its borders confirms waltz's argument that the anarchic nature of the international system encourages states to use defensive and moderate measures to attain security (1979: 92).

Furthermore, Russian military intervention and annexation of Crimea demonstrate the West's miscalculation of the length that Russia would go to protect its strategic objectives and its security. It was unacceptable for Russia to have a neighbor and a strategic territory such as Crimea fall into the hands of the West. Moreover, Russia's actions to annex Crimea because of NATO's expansion policy in eastern Europe show that Russia was trying to balance power with NATO in the region. This is because several states in eastern Europe had already joined NATO and Ukraine Russia's neighbor was also making plans to become a NATO member. Russia understood that doing nothing in Ukraine means allowing NATO to gain more influence and power in the region. To prevent this from happening, Russia decided to invade Ukraine and annex Crimea. Russia's annexation of Crimea in 2014 shows its willingness to balance power with NATO in eastern Europe and to prevent NATO from becoming too powerful in the region. This action taken by Russia to balance power in the region validates the argument made by Waltz in his defensive realism theory that the balance of power is an "iron law" that states can use to assure their survival by making sure that their rivals do not grow too powerful (1979: 188).

On the other hand, though the actions taken by the Russian government to annex Crimea because of NATO's expansion can be seen as defensive, how Russia carried out the actions is offensive. In other words, how Russia intervened and annexed Crimea from Ukraine during the Ukraine Crisis of 2014 is an example of an aggressive/offensive state behavior in international politics as explain by John Mearsheimer in his offensive realism theory. This is because reports from the Ukrainian government indicated that there was a significant influx of Russian troops in eastern Ukraine before the annexation of Crimea by Russia in 2014 (Becker, Cohen, Kushi \& McManus 2016: 120). Ukraine was a sovereign state before this conflict; however, Russia turned a blind eye to Ukraine's sovereignty and intervened militarily by sending its military into Crimea to take control over key installations such as airports and state buildings. The fact that Russia acts rationally, albeit aggressively by sending its military into Ukraine and illegally annexing Crimea without Ukraine's permission to achieve its security goals makes Russia looks like an aggressor. In other words, Russia's actions in Crimea during the Ukraine crisis make Russia look like an offensive realist as describe by Mearsheimer (2001). 
Further, Mearsheimer explains in his offensive realism theory that States are rational actors, and they think strategically to maximize their prospects for survival (Mearsheimer, 2001: 31). Russia's decision to intervene and annex Crimea because of NATO's expansion policy is a rational action taken by Russia to maximize its prospects for survival in an international system that is anarchy. Likewise, the aggressive manner in which Russia took to intervene and eventually annex Crimea in 2014 validates the assumption of offensive realism that states use aggressive/offensive measures to ensure their survival. However, it contradicts the assumption of Waltz's defensive realism that states are not intrinsically aggressive (1979: 161).

Next, the third assumption of Mearsheimer's offensive realism theory assumes that powerful states are never certain about other states' intentions, which makes them use offensive actions to guarantee their security (Mearsheimer, 2010: 73-74). Russia's annexation of Crimea in 2014 validates this third assumption of offensive realism on the perception of threat and survival because Russia is an example of the powerful states that Mearsheimer describes in his offensive realism theory. And as a powerful state, Russia was not certain about NATO's intentions near its borders; it perceived NATO's expansion on its borders as a threat that is why it acted aggressively by sending its military into Crimea to seize control of the territory. As Mearsheimer explains, great powers like Russia are always sensitive to potential threats near their home territory (2014: 18). Thus, Russia would rather destroy Ukraine as a functional state than allow it to become a Western stronghold on Russia's doorsteps.

Moreover, Russia's annexation of Crimea to prevent NATO's enlargement policy in eastern Europe validates the assumption of both offensive realism and defensive realism that great powers are the main actors in international politics and that the international system is anarchy (Waltz, 1979: Mearsheimer, 2001). A smaller or a weaker country such as Sudan or Luxemburg would not have had the effrontery to march into Crimea and forcefully annexed it from Ukraine. Russia dared to carry out this aggressive action because it is one of the offensive great powers that Mearsheimer describes in his offensive realism theory. Besides, Russia's military might and its military capabilities that were stationed in the Crimean port of Sevastopol made it possible for it to annex Crimea easily from Ukraine. This validates the assumption of both offensive and defensive realism that great powers possess the greatest military capabilities to shape the character of the international system (Waltz 1979; Mearsheimer, 2001). 


\subsection{Other Findings \\ 6.2.1. Great Power Status}

On the other hand, several themes also emerged from my data to show that there are alternative arguments on the rationale behind Russia's intervention and annexation of Crimea in 2014. As an example "great power status" is one of the central themes that emerged from my data to support these alternative arguments. For instance, one article by Steven Ward stated that "Russia intervened and annexed Crimea because of Putin's desire to restore Russia's great power status" (2014). Another article stated that "Russia annexed Crimea in 2014 because it wanted to show the world that despite the collapse of the Soviet Union; Russia is still a great power" (Gigitashvili, 2016). These statements from my data reveal that Russia also intervened and annexed Crimea during the Ukraine Crisis of 2014 because it wanted to restore its status as a great power. The question is why Russia was trying to restore its status as a great power?

The reason why Russia wanted to restore its status as a great power is that during the Post Cold War era, the US and its Western allies no longer treated Russia as a "great power." The most important manifestation of Russian demotion from the ranks of great power was the new willingness by the West to encroach upon what had been understood during the Cold War as Russia's sphere of influence. The expansion of NATO in eastern Europe and the growing Western ties with Ukraine and other former member states of the Soviet Union in eastern Europe is evidence that the West had failed to accord Russia with the status of great power that it had before the collapse of the Soviet Union. However, Russia has always considered itself as a "great power" (Nixey, 2015), and Russian state officials understood that great power status means that Russia must have hegemony and exercise some form of leadership including domination over its region (eastern Europe). They understood that having hegemony and dominance in eastern Europe would also ensure Russia's security in the region. As Mearsheimer explains in his offensive realism theory the best way for great powers like Russia to ensure their security is to achieve hegemony (Mearsheimer, 2001: 61).

Mearsheimer believes that achieving hegemony would eliminate any possibility of a challenge by another great power (Ibid). Russia intervened and annexed Crimea because it felt that its dominance in the region was threatened by the expansion of NATO since many countries in eastern Europe that were former members of the Soviet Union were joining the Alliance. Russian state officials understood that intervening and annexing Crimea will show Russia's dominance in the region and will eliminate any challenge from the West. Additionally, Russia's decision to intervene and annex Crimea during the Ukraine Crisis of 2014 was a rational and strategic move made by Russia to ensure its survival. This move by Russia validates the fifth assumption of 
offensive realism that states are rational actors and they think strategically to maximize their prospects for survival (Mearsheimer, 2001: 31).

\subsubsection{Nationalism and National Identity}

Another major theme that emerged from my data to show the rationale behind Russia's intervention and eventual annexation of Crimea is "Nationalism and National identity."

For example, one article by Eleanor Knott stated that "Russia annexed the Crimean peninsula in March 2014 because it sees the people of Crimean as Russians" (2015). Another article stated that "Russia did what it did in Crimea during the Ukraine crisis of 2014 because of its nationalist worldview that sees Crimea as part of greater Russia and a victim of ever-encroaching Western hostilities" (Fisher, 2014). The statements above obtained from my data show that Russia decided to intervene in Ukraine and annexed Crimea during the Ukraine Crisis of 2014 because it wanted to protect the "Russian civilization" or "Russian national identity" since it sees the people of Crimea and Russia as one. This finding is similar to the findings of other scholars discussed in the literature review section of this paper which revealed that Russia intervened and annexed Crimea in 2014 to protect the Russian identity (Morozov, 2014; Teper, 2015; Allison, 2014; Zhurzhenko, 2014; Averre, 2016).

Russian President Vladimir Putin made Russian citizens in Russia believe that the "Russian civilization" or identity which extends beyond Russia's borders was under threat from the West and that Russia's actions in Crimea were to protect the Russian civilization or identity from the western culture. This is because senior state officials in Russia view the people of Russia and Crimea as one. The reason why Russian officials see the people of Crimea and Russia as one is because the majority of the Crimean population is ethnically Russian (Knott, 2015). Putin interpreted and understood that Crimea and Russia have a special historical link and that the majority of the Crimean population is ethnic Russians. This is the reason why he decided to act by sending Russia's military into Crimea to annex the territory from Ukraine under the guise of protecting the majority ethnic Russian population in Crimea whom he identified as Russians. Putin's interpretation and subsequent reaction validate the argument made by Weldes in his national interest concept that before states officials can act on behalf of a state, they must first engage in a process of interpretation to understand the situation that the state face and how they should respond to it (1996: 276).

Similarly, Russian state officials used nationalist rhetoric to describe the people of Russia and Crimea as one, and this rhetoric paid particularly well by increasing public support for Putin's action in Crimea and increasing Putin's popularity rating in Russia (Kolsto, 2016: 702). Russian state officials 
use this rhetoric to gain the support of the majority of Russian citizens in Russia especially Russian nationalists and to make them believe that protecting the Russian identity in Crimea was good for Russia's national interest. This nationalistic rhetoric used by senior Russian state officials to win the support of Russian citizens in Russia confirms Weldes' argument that the concept of national interest can act as a rhetoric device through which the legitimacy and political support for state action are generated (1996: 276). Putin and other senior Russian state officials used the nationalistic rhetoric as a device to generate support for Russia's action in Crimea from ordinary Russian citizens in Russia.

\section{Consequences of Russia's Action in Crimea \\ 7.1 Tension between NATO and Russia}

Russia's intervention and annexation of Crimea during the Ukraine Crisis of 2014 have led to several consequences. One of the consequences is that it has caused serious tension between NATO and Russia (Monaghan, 2014). In other words, Russia's intervention and eventual annexation of Crimea in 2014 have made NATO's relationship with Russia to be more difficult than it has been any time since the end of the Cold War. The NATORussia relations have been central in the evolution of Russia's relationship with the West since the collapse of the Soviet Union (Sharyl, 2015: 153). However, the relationship has gotten worse in recent years as a result of Russia's forceful intervention and annexation of Crimea in 2014. On the one hand, NATO accuses Russia of aggression for intervening and illegally annexing Crimea from Ukraine. On the other hand, Russia rejects NATO's accusation and argues that its actions in Crimea were taken to secure its interest against NATO's expansion and as a response to a crisis provoked by the US and the EU (Monaghan, 2014).

These arguments made by both sides emphasize tension and the lack of trust between them. The tensions between NATO and Russia created by the Ukraine Crisis of 2014 threatens not only to devastate our society but also unravel all progress made in building peace and security in the world since the end of the Cold War. Anthony Ian contends that there is little prospect for lasting improvements in the NATO-Russia relations (2012: 119). Nevertheless, efforts must be made by Western policymakers and Russia to repair the damages that the Ukraine Crisis of 2014 created to the NATORussian relations. This is necessary for the world to enjoy international peace and stability.

\subsection{Increase Military Spending}

Russia's intervention and eventual annexation of Crimea in 2014 have forced many European countries to increase their military spending. Many of 
these European countries see Russia's intervention and annexation of Crimea as a threat to their own security. For instance, after Russia annexed Crimea in 2014, the government of Ukraine decided to increase its military spending significantly (Beswick, 2019). President Petro Poroshenko announced that Ukraine would increase its military spending to almost 3 billion US dollars (Ibid). Several central and north European countries bordering Russia also announced increases in their military spending as a direct response to Russia's actions in Crimea during the Ukraine Crisis of 2014. Most European countries of the former Soviet Union such as Latvia and Lithuania were among the top 10 countries which increase their military spending in 2018 due to the perception of threat from Russia with totals of $24 \%$ and $18 \%$ respectively (Ibid). Similarly, Finland which shares a land border with Russia and Sweden a sea neighbor both increased their military spending between 2017 and 2018 as a result of Russia's behavior in Crimea in 2014. Further, in the wake of the Ukraine crisis which led to Russia's annexation of Crimea, the United States NATO's dominant power seized on the crisis to drive home its argument that allies must spend more on their own defense. It called on NATO member states to recommit to a long-standing target that NATO members should spend $2 \%$ of their economic output on defense. However, while NATO countries made 'pledges' to increase their military spending to $2 \%$ this is all most have done to meet the target.

\subsection{International Sanctions}

In response to Russia's intervention and annexation of Crimea in 2014, international sanctions were imposed on Russia by foreign countries. The sanctions were imposed by the EU, USA, Canada, and several other countries against individuals, businesses, and officials from Russia and Ukraine who played roles in the Ukraine Crisis of 2014 (Davis, 2016: 184-185). Other measures taken by the EU and the USA against Russia include trade embargoes and restrictions on finance (Ibid). Additionally, the Ukrainian government also carried out several sanctions against Russia for intervening and annexing Crimea in 2014. For instance, the Ukrainian government banned Russian planes from flying through Ukrainian airspace. The international sanctions had several negative effects on Russia. As an example, the sanctions lowered Russia's dollar earnings from energy exports, which weakened the financial positions of its banks, businesses, and government (Davis, 2016: 185).

Moreover, the sanctions also contributed to the collapse of the Russian ruble. Russia responded to the international sanctions by adopting numerous countermeasures such as imposing a total ban on food imports from the EU, USA, Norway, Canada, and Australia. Concerning Ukraine, Russia imposed restrictions on the export of industrial and agricultural goods to Russia, cut 
energy subsidies, and demanded pre-payment of gas supplies (Gardner, 2014). In March 2015, Russia also prohibited Western IT firms that were operating in Russia from bidding for state contracts. The Western sanctions imposed on Russia because of its actions in Crimea in 2014 are regularly extended every year. The international sanctions have caused economic damages to both Russia and Western states. In June 2019, President Putin confirmed that since 2014 Russia has lost about $\$ 50$ billion due to international sanctions imposed against Russia because of its actions in Crimea (CSFI, 2021). At the same time, the EU lost $\$ 240$ billion and the USA lost $\$ 17$ billion (Ibid). These figures show that the international sanctions that resulted from Russia's intervention and eventual annexation of Crimea are having a negative effect not just on Russia but also on Ukraine and several Western countries.

\section{Conclusion}

This paper has examined why Russia intervened and eventually annexed Crimea during the Ukraine Crisis of 2014. The paper argued that Russia intervened and annexed Crimea during the crisis because of NATO's expansion policy in eastern Europe. The results of this study support the central thesis/argument stated above. However, the results of this study also revealed that there are alternative arguments on the rationale behind Russia's intervention and eventual annexation of Crimea during the Ukraine Crisis of 2014. As can be seen from the findings of this study, the implication of focusing on NATO's expansion policy as the main motive behind Russia's intervention and annexation of Crimea is that people might ignore the role that other factors such as nationalism, identity, and Russia's quest for great power status played in influencing Russia's behavior.

As this paper suggests, it is possible to argue that NATO's expansion policy in eastern Europe and other factors pushed Russia to intervened and eventually annexed Crimea during the Ukraine Crisis of 2014. I acknowledge the limitations of this study. Another kind of evidence could be used in place of the statements from the articles. However, this evidence is the best source I could go after due to time constraints. Also, this study being a case study research provide little basis for generalization of its findings. This paper was not able to address other dimensions of the Ukraine Crisis of 2014 such as the legality of Russia's intervention and annexation of Crimea in 2014; it would be interesting to study this area. Thus, future research on this topic can focus on the legality of Russia's intervention and annexation of Crimea under international law (the UN Charter). This will contribute to a greater understanding of the contemporary debate on Russia's behavior in Crimea during the crisis. Likewise, future research on this topic can look at the political, economical, and social changes that have taken place in the Crimean peninsula after it was annexed by Russia seven years ago. As indicated in this 
paper, Russia's actions in Crimea during the Ukraine crisis have worsened the NATO-Russian relations, and this has caused global security challenges. To resolve this problem, I would suggest more collaboration between the government of Russia and NATO member countries.

\section{References:}

1. Antunes, Sandrina \& Camisao, Isabel. (2018). Introducing Realism in International Relations Theory. E-International Relations, February 27. Available at: https://www.e-ir.info/2018/02/27/introducingrealism-in-international-relations-theory/.

2. Abebe, Daniel. (2009). "Great Power Politics and the Structure of Foreign Relations Law". University of Chicago Public Law\& Legal Theory Working Paper, No. 256.

3. Allison, Roy. (2014). Russian deniable intervention in Ukraine: how and why Russia broke the rules. International Affairs, 90 (6), November 2014, 1255-1297.

4. Averre, Derek. (2016). The Ukraine Conflict: Russian Challenges to Security Governance. Europe Asia Studies, 68 (4), 699-725.

5. Bebler, Anton. (2015). Crimea and the Russian-Ukraine Conflict. Romanian Journal of European Affairs, 15 (1), 35-54.

6. Becker, Michael E., Cohen, Mathew S., Kushi, Sidita \& McManus, Ian P. (2016). Reviving the Russian Empire: The Crimean Intervention through a Neoclassical Realist Lens. European Security, 25:1, 112133.

7. Bennet, Andrew. (2010). Process Tracing and Causal Inference, Chapter 10 in Brady, Henry E. and David Collier (Eds). Rethinking Social Inquiry: Diverse Tools, Shared Standards. $2^{\text {nd }}$ ed. Lanham, MD: Rowman and Littlefield.

8. Beswick, Emma. (2019). EU Countries Increase Military Spending due to' Growing Perceptions of Russia Threat': Report. Euronews, July 26. Available at: https://www.euronews.com/2019/04/29/eucountries-increase-military-spending-due-to-growing-perceptions-ofrussia-threat-report.

9. Brent, Robinson. (2018). "Are The Russians Offensive Realists?." Risk \& Politics July 6. Available at: https://riskandpolitics.com/2018/07/06/are-the-russians-offensiverealists/.

10. Buchanan, Kelly. (2014). Crimean History, Status, and Referendum. Library of Congress. March 13.Available at: https://blogs.loc.gov/law/2014/03/crimean-history-status-andreferendum/ 
11. Christie, Edward Hunter. (2015). "Sanctions after Crimea: Have they worked?." NATO Review, 13 July. Available at: https://www.nato.int/docu/review/articles/2015/07/13/sanctions-aftercrimea-have-they-worked/index.html.

12. Costea, Ana-Maria. (2016). The Ukraine Crisis - An Unpredictable Event? CES working paper, 8 (3), 333-347.

13. Creswell, W. J. (2014). Research Design. Qualitative, Quantitative, and Mixed Methods Approaches, $4^{\text {th }}$ edition, London: SAGE Publications, Inc.

14. CSFI. (2021). A Competition in Great Dislike Between Russia and the West: A View From Moscow. CSFI.ORG, April 14, Available at: https://www.csfi.org/2021-04-14-western-sanctions-on-russia.

15. Davis, Christopher Mark. (2016). The Ukraine Conflict, EconomicMilitary Power Balances and Economic Sanctions. Post-Communist Economies, 28 (2), 167-198.

16. Deutsche, Welle. (2014). 'Ukraine's Forgotten Security Guarantee: The Budapest Memorandum'. Deutsche, Welle, 05 December. Available at: https://www.dw.com/en/ukraines-forgotten-securityguarantee-the-budapest-memorandum/a-18111097.

17. Ericson, Richard E. \& Zeager, Lester A. (2015). Ukraine Crisis 2014: A study of Western Strategic Interaction. De Gruyter, 21(2), 153-190.

18. Fisher, Max. (2014). "Everything you need to know about the Ukraine Crisis", Vox, September 3. Available at: https://www.vox.com/2014/9/3/18088560/ukraine-everything-youneed-to-know.

19. Gardner, Andrew. (2014). Russia Rejects Compromise Proposed by the European Union. Politico, June 16. Available at: https://www.politico.eu/article/russia-cuts-gas-to-ukraine/

20. Gerring, John. (2017). A typology of research designs. Chapter 7 in Case study Research: Principles and Practices. $2^{\text {nd }}$ ed. Cambridge University Press.

21. Gerring, John. (2017). Qualitative Methods. Annual Review of Political Science, 20, 13-36.

22. Gigitashvili, Givi. (2016). "Russia's National Interest and Foreign Policy Preferences." Latvian Institute of Foreign Affairs, November 10. Available at: https://www.lai.lv/viedokli/russias-nationalinterests-and-foreign-policy-preferences-554.

23. Hsieh, Hsiu-Fang \& Shannon, Sarah E. (2015). Three Approaches to Qualitative Content Analysis. Qualitative Health Research, 15(9), 1277-1288. 
24. Ian, Anthony. (2012). NATO-Russian Relations: The State of the Relations and Future Prospects. The Polish Quarterly of International Affairs, 21 (1), 119-140.

25. Kamp, Karl-Heinz. (2014). From Wales to Warsaw: NATO's Future beyond the Ukraine Crisis. American Foreign Policy Interests, 36 (6), 361-365.

26. Knott, Eleanor. (2015). Do Crimeans See Themselves as Russians or Ukrainians? It's Complicated. The Washington Post, December 03. Available at: https://www.washingtonpost.com/news/monkeycage/wp/2015/12/03/do-crimeans-see-themselves-as-russian-orukrainian-its-complicated/.

27. Lane, D. (2016). The International Context, Ukraine and the Drift to East-West Confrontation. International Critical Thought, 6 (4), 623644.

28. Larsen, H.B.L., 2014. Great Power Politics and the Ukrainian Crisis: NATO, EU, and Russia after 2014. Report 2014:18, Copenhagen: DIIS, Danish Institute for International Studies.

29. Lindley-French, J. (2014). Ukraine: Understanding Russia. The RUSI Journal, 159 (3), 36-39.

30. Masters, Jonathan. (2020). Ukraine: Conflict at the Crossroads of Europe and Russia, Council on Foreign Relations, February 05. Available at: https://www.cfr.org/backgrounder/ukraine-conflictcrossroads-europe-and-russia.

31. Mearsheimer, J. (2001). The Tragedy of Great Power Politics. New York: W.W.Norton.

32. Mearsheimer, J. (2010). "Structural Realism," in Tim Dunne et al.eds, International Relations Theories: Discipline and Diversity (Oxford: Oxford University Press, 2010), chapter 4.

33. Mearsheimer, J. (2014). Why the Ukraine Crisis is the West Fault: The Liberal Delusions That Provoked Putin. Foreign Affairs, 93 (5),77-89.

34. Monaghan, A. (2014). The Ukraine Crisis and NATO-Russian Relations. NATO Review, July 01. Available at: https://www.nato.int/docu/review/articles/2014/07/01/the-ukrainecrisis-and-nato-russia-relations/index.html.

35. Morozov, V. (2017). Russian Society and the Conflict in Ukraine: Masses, Elites and Identity. E-International Relations, May 01.

Available at: https://www.e-ir.info/2017/05/01/russian-society-andthe-conflict-in-ukraine-masses-elites-and-identity/.

36. Nixey, J. (2015). Is Russia still a Key World Power? BBC News, December 21. Available at: https://www.bbc.com/news/world-europe34857908 . 
37. Pashakahanlou, A. (2018). The Past, Present and Future of Realism. EInternational Relations, January 15. Available at: https://www.eir.info/2018/01/15/the-past-present-and-future-of

realism/\#: :text=Waltz's\%20defensive\%20realism\%20offers\%20a,ce ntric\%20theory\%20of\%20international\%20politics.\&text=In\%20this $\% 20$ regard\%2C\%20differentiations\%20between,Waltz\%20(1979\%2 C\%20161).

38. Reuters. (2014). Putin says Annexation of Crimea partly a Response to NATO Enlargement. Reuters, April 17, Available at: https://www.reuters.com/article/us-russia-putin-natoidUSBREA3G22A20140417.

39. Sharyl, C. (2015). NATO-Russia Security Challenges in the Aftermath of Ukraine Conflict: Managing Black Sea Security and Beyond. Journal of Southeast European and Black Sea Studies, Vol.15 (2), 151177.

40. Silverman, D. (2006). Interpreting Qualitative Data: Methods for Analyzing Talk, Text and Interaction, SAGE Publications Ltd: London.

41. Sperling, James \& Webber, Mark. (2017). NATO and the Ukraine Crisis: Collective Securitization. European Journal of International Studies, 12 (1), 19- 46.

42. Steinsson, S. (2014). John Mearsheimer's Theory of Offensive Realism and the Rise of China. E-International Relations, March 06. Available at: https://www.e-ir.info/pdf/47402.

43. Kuzio, T. \& D'Anieri, P. (2018). The Causes and Consequences of Russia's Actions towards Ukraine. E-International Relations, June 16. Available at: https://www.e-ir.info/2018/06/16/the-causes-andconsequences-of-russias-actions-towards-ukraine/.

44. Teper, Y. (2015). Official Russian Identity Discourse in light of the Annexation of Crimea: National or Imperial? Tandfonline, 32 (4), 378396.

45. Treisman, D. (2016). Why Putin Took Crimea: The Gambler in the Kremlin. Foreign Affairs, 95 (3), 47-54.

46. Walker, E. (2014). What's Behind Russia's Moves in Ukraine? Fear of NATO. Los Angeles Times, March 04. Available at: https://www.latimes.com/opinion/la-xpm-2014-mar-04-la-oe-walkerukraine-nato-expansion-20140304-story.html.

47. Waltz, K. (1979). Theory of International Politics. Reading, MA: Addison-Wesley.

48. Ward, S. (2014). How Putin's Desire to Restore Russia to Great Power Status Matters. The Washington Post, March 06. Available at: https://www.washingtonpost.com/news/monkey- 
cage/wp/2014/03/06/how-putins-desire-to-restore-russia-to-greatpower-status-matters/.

49. Weldes, J. (1996). "Constructing national interests", European Journal of International Relations 2(3), 275-318.

50. Wolff, A. (2015). The future of NATO enlargement after the Ukraine Crisis. International Affairs (London), 91 (5), 1103 -1121.

51. Zamawe, F C. (2015). The implication of using NVivo software in qualitative data analysis: Evidence-based reflections. Malawi Medical Journal, 27/1, 13-15.

52. Zhurzhenko, T. (2014). A divided nation? Reconsidering the role of identity politics in the Ukraine crisis. Die Friedens-Warte, 89 (1/2), 249-267.

53. Ziegler, C E. (2020). A Crisis of Diverging Perspectives: U.S-Russian Relations and the Security Dilemma. Texas National Security Review, 4 (1), 12-33. 